\title{
Maharanga squamulifera (Boraginaceae), a New Species from Thailand and its Morphological and Phytogeographical Implications
}

\author{
Harald Riedl \\ Naturhistorisches Museum, Botanische Abteilung, Burgring 7, A-1014 Wien, Austria
}

ABSTRACT. Maharanga squamulifera Riedl is described from northern Thailand, a remarkable extension of the range of the genus. Its most important characters are the presence of linear scales at the base of the corolla, the smooth and glabrous tips of the anthers, the scarcely distinct differences in the attachment of the filaments, and the distinctly glabrous nutlets.

Maharanga squamulifera Riedl, sp. nov. TYPE: Thailand. Chiang Mai: northern Thailand, higher elevation of Doi Chiang Dao, 1,900-2,100 $\mathrm{m}$, on rocky mountain ridge of limestone near summit, 26 Sep. 1971, Gen Murata, Kunio Iwatsuki \& Chamlong Pengklai T-15282 (holotype, L; isotype, KYO).

Herba pluricaulis caulibus simplicibus, foliis basalibus rosulatis, caulinis densis, lineari-lanceolatis vel anguste lanceolatis, acutis, supra subtusque densissime appresse strigosis, bracteis calyce brevioribus, calyce in tertia parte inferiore vel usque ad medium connato, 7-10 $\mathrm{mm}$ longo, corolla opace purpureo-coerulea, $1.2-1.3 \mathrm{~cm}$ longa, clavata, paulo ultra medium inter lobos profunde longitudinaliter plicata, extra densissime appresse pilosa, intus ad basin filamentorum et ad imam basin barbata, annulis 5 extra impressis ad insertionem filamentorum ornata, squamulis 5 elongato-linearibus ad basin in loco annuli nectariferi instructa, antheris basi sagittata cohaerentibus, inclusis, apice sterili truncatis, stylo corollam longe superante valde insignis.

Plants perennial, with a sterile rosette. Stems several, 35-60 cm high, unbranched, erect, brownish to dark brown at lower part, densely covered with patent, ferrugineous hairs ca. $2 \mathrm{~mm}$ long. All leaves linear-lanceolate, acute, darker green on upper side, pale on lower, with revolute margins, densely covered with very slender, \pm appressed hairs arising from circles of mineralized cells on the upper side only; rosette leaves $6-12 \mathrm{~cm}$ long, $0.5-1.2 \mathrm{~cm}$ wide at the broadest place slightly above middle, gradually tapering into a winged petiole $2-4 \mathrm{~cm}$ long; lower stem leaves already dry at flowering time, middle and upper leaves sessile, very dense, gradually decreasing in size, $2-6.5 \mathrm{~cm}$ long, $0.3-1(-1.2)$ $\mathrm{cm}$ wide, tapering toward base from about middle, uppermost leaves broadest near base. Cymes usually in pairs, with 7-12 flowers, scorpioid, about 2-2.5 $\mathrm{cm}$ diam., elongated to about $3.5 \mathrm{~cm}$ after flowering, sometimes a reduced cyme or a single flower in axil of uppermost leaf; bracts linear, broadest at base, 4-12 mm long, 1.2-2 mm wide, acute, otherwise like the leaves. Pedicels densely covered with patent, ferrugineous hairs, $1-5 \mathrm{~mm}$ long in flower, elongated to $5-7 \mathrm{~mm}$ afterwards, in single flowers up to 10 $\mathrm{mm}$, straight or slightly curved. Calyx 7-10 mm long, lobes free in upper half or two-thirds, linear to linear-lanceolate or linear-triangular in flower, narrowly triangular later on, acute, densely covered with ferrugineous hairs, hairy also on inner side. Corolla dark purplish blue, $1.2-1.3 \mathrm{~cm}$ long, \pm clavate, in compressed state about $5 \mathrm{~mm}$ wide, constricted below lobes, with 5 deep folds from the sinuses between lobes downwards for about twothirds of corolla length, outside densely covered with short, appressed, retrorse hairs except for lowermost part, with 5 deep, ringlike to elliptic impressions where the filaments attached inside; lobes from a truncate, slightly convex base abruptly tapering into shortly triangular apex, acute, revolute; corolla inside bearded at the very base and at base of filaments, sparsely hairy between these two rings of hairs, glabrous above upper ring; scales 5, linear, ca. $1 \times 0.2 \mathrm{~mm}$, rounded at apex, resembling faucal appendages, located at corolla base and replacing the nectary ring. Filaments inserted ca. $2.5-3 \mathrm{~mm}$ above corolla base, $4.5 \mathrm{~mm}$ long, with a broadly lanceolate lower part up to $1 \mathrm{~mm}$ wide and unequal in width among the 5 stamens, with medial or eccentric vein, tapering into a flattened-filiform upper part; anthers attached at ca. $1.5 \mathrm{~mm}$ above their base, 5.5(-6) mm long, sagittate, coherent with their bases, completely included in corolla, sterile apex truncate, $1.5 \mathrm{~mm}$ long. Style filiform, $1.3-1.6 \mathrm{~cm}$ long, distinctly longer than corolla; stigma minute, bilobed. Nutlets 4 , known only at a very young stage, hood-shaped, rounded at apex, sessile, with a large, rhombic, basal attachment scar, not papillate or muriculate.

The most peculiar features of Maharanga squamulifera are the scales in place of a nectary ring at the corolla base. They strongly resemble the faucal scales present in many other genera of the Bor- 
aginaceae and absent from most genera of the Lithospermeae, to which Maharanga A. DC. belongs. The attachment of filaments, which was described by Johnston (1954) in some detail, is not so typical in $M$. squamulifera as in the other species of $M a$ haranga. Two filaments have a distinctly eccentric midvein, but their attachment is not markedly oblique or clearly arcuate when the vein is medial. Furthermore, the filaments in $M$. squamulifera are not distinctly decurrent, and they differ in the width of their lower half. Another character that sets the new species apart from the other species of Maharanga is the sterile tip of the connective, which is toothless and without ascending hairs along its margin. The immature nutlets are glabrous, smooth, and neither papillate nor muriculate, but this aspect might change at maturity. The connective and nutlets are more similar to Onosma L. than to other species of $M a$ haranga. The scales at the corolla base are unique to $M$. squamulifera. However, the calyx lobes, which are free only in their upper part, the longitudinal folds of corolla, the impression at the place of attachment of filaments, and the shape of corolla lobes are typical for Maharanga. Pollen grains have not been examined for this study. Although Maharanga squamulifera resembles Onosma in the nutlets and connective, the differences are sufficient to include it in Maharanga and to support the separation of Maharanga from Onosma.

Maharanga is distributed in the central and eastern Himalayas and adjacent parts of southwestern China (Yunnan) and India (Assam). The discovery of $M$. squamulifera is a remarkable extension of the genus range in southeastern Asia and the first report from Thailand. Assam is the nearest region where other members of the genus grow. As presently circumscribed, Maharanga includes ten species and is centered in Nepal.

Paratype. NORTHERN THAILAND. Payap: Doi Chiengdao, low brushwood with stunted trees on exposed ridge, ca. 2,000 m, 7 Dec., E. Hennipman 3286 (L).

Acknowledgment. I thank Ihsan Al-Shehbaz for help with the manuscript.

Literature Cited

Johnston, I. M. 1954. Studies in the Boraginaceae, XXVI. Further revaluations of the genera of the Lithospermeae. J. Arnold Arbor. 35: 1-81. 


\section{$2 \mathrm{BHL}$ Biodiversity Heritage Library}

Riedl, Harald. 1994. "Maharanga squamulifera (Boraginaceae), a New Species from Thailand and Its Morphological and Phytogeographical Implications." Novon a journal of botanical nomenclature from the Missouri Botanical Garden 4, 394-395. https://doi.org/10.2307/3391451.

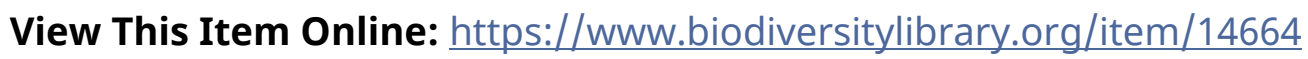

DOI: https://doi.org/10.2307/3391451

Permalink: https://www.biodiversitylibrary.org/partpdf/122191

\section{Holding Institution}

Missouri Botanical Garden, Peter H. Raven Library

\section{Sponsored by}

Missouri Botanical Garden

\section{Copyright \& Reuse}

Copyright Status: In copyright. Digitized with the permission of the rights holder.

License: http://creativecommons.org/licenses/by-nc-sa/3.0/

Rights: https://biodiversitylibrary.org/permissions

This document was created from content at the Biodiversity Heritage Library, the world's largest open access digital library for biodiversity literature and archives. Visit BHL at https://www.biodiversitylibrary.org. 